\title{
The Reflection of Society Culture in Visual Art Illustration of Javanese Manuscript
}

\author{
Nuning Damayanti Adisasmito \\ Faculty of Visual Art and Design, Institut Teknologi Bandung \\ nydamayanti64@gmail.com
}

\begin{abstract}
The tradition of writing and drawing in illustration was found in the old manuscript. Some parts of those old manuscripts show unique illustrations as well as the local identity of Nusantara's society. The manuscript reflects the society culture of thinking and aesthetic achievement of visual art. The Illustrations of old Javanese manuscripts were well documented and has various representation in visualization art and style, drawing method, theme, and visual objects, even though the visualization of the visual concepts is practically similar to another. The illustration in the old Javanese manuscript in 1800-1920 shows continuous correlation of the visual language in the past era to the present and becomes the characteristics of Indonesian visual states. It reflects the structured illustration and style as well as expression symbol of the Javanese society in that era. Illustration of the old Javanese manuscript in the year 1800-1920 has changed and developed its visual state as the interaction between the animism in the Pre-Hinduism era, cultural paradigm of Hinduism-Buddhism, Islamic and Colonialism. The illustration style of the old Javanese manuscripts is decorative, naturalistic, realistic, simplified form and deformative.
\end{abstract}

Keyword : illustration,Indonesian illustration tradition, colonialism, old Javanese manuscript.

\section{Refleksi Budaya Masyarakat dalam Ilustrasi Seni Visual Manuskrip Jawa}

Tradisi menulis dan menggambar ilustrasi ditemukan pada manuskrip lama Nusantara. Sebagian dari manuskrip lama Nusantara itu memuat ilustrasi yang unik dan khas menjadi identitas masyarakat Nusantara. Naskah-naskah tersebut merefleksikan ketinggian budaya berpikir dan pencapaian estetik bidang seni rupa pada masyarakat Jawa dimasa itu. Sejumlah Manuskrip Jawa kuno didokumentasi dengan cukup baik, diantaranya merepresentasikan konsepsi seni dan ga-ya hidup pada masanya, juga memuat metode menggambar, objek visual, tema, dan konsep estetik yang tampaknya memiliki kesamaan satu dengan yang lain. Hasil analisis pada Ilustrasi yang dipilih dalam manuskrip Jawa periode tahun 1800-1920 menunjukkan adanya benang merah yang muncul secara terus-menerus bahkan hingga saat ini. Wujud visual art ilustrasi menjadi ciri khas ilustrasi Indonesia, gaya ilustrasi yang terstruktur dan menjadi simbol ekspresi di era itu. Konsep estetik dan wujud visual Ilustrasi manuskrip Jawa kuno mengalami perubahan dan pengembangan menunjukan gambaran dinamisasi interaksi antara paradigma animisme era Pra-Hindu, budaya Hinduisme-Buddha, Islam dan Kolonialisme. Gaya ilustrasi manuskrip Jawa kuno adalah bentuk dekoratif, naturalistik, realistis, disederhanakan dan deformatif.

Kata kunci: ilustrasi, ilustrasi tradisi Indonesia, kolonialisme, naskah kuno Jawa 


\section{INTRODUCTION}

Manuscripts are artefacts recording culture achievement and thinking enrichment of a nation and are the sources of culture knowledge of the past. Every people in the world has old valuable manuscripts - which are important records on the existence of a nation - and so do the Indonesians. Indonesian ancestors recorded their culture of the past on various kinds of manuscripts, spread in the whole country of Indonesia. The number and diversity of the manuscripts show that Indonesians are the people having the intelectuality and the capability of expressing ideas, thoughts, and culture of thinking. into writing. The society culture of expressing ideas and thinking is wrapped in various kinds of manuscripts - some of which are expressed in ornaments, illuminations, and illustrations. These drawings show unique and typical visualization adjusted to the background of the society and the their functions.

The writing culture of the Javanese has been consensus for ages. This can be proven from the fact that manuscript artefacts can still be traced from the periods of the beginning of such Javanese kingdoms as Tarumanagara, Singosari, Majapahit, Pajang, Demak, Surakarta, and Yogyakarta. Some manuscripts reflect illustrations, and are well documented in both Indonesian and overseas libraries. Modernization, however, has made these valuable manuscripts uncomprehensible for the young generation today.

To trace the creation of Javanese manuscripts, we cannot put their correlation to the visual art of leather puppets aside, because we can draw an analogy between the stories of the shadow plays and those of important events of the kingdoms and their kings. The development of Javanese culture, therefore, can be considered to be parallel to the puppet stories. Comprehending the plot of the stories and their characters is an attempt to understand the characters and life philosopy of the Javanese. Javanese manuscripts which can still be appreciated are those of the 18th and the begining of the 20th Centuries. They reflect the stories of periods of the Majapahit Kingdom which then change and develop because of the adaptation of Islamic norms. Accordingly, in tracing the creation of the manuscripts of those eras, we cannot ignore either the role of Islam religion or the political factors of the Javanese supremacy towards the Dutch colonial culture.

\section{Javanese Manuscripts as Culture Products}

Art is a culture product which become one of the parameters to determine the values of a society. Art should represent sense or values and have visualisation. This kind of art product is a bunch of inheritences of comprehensible art works based on the society comprehension of that era. Considering various kinds of functions and background of art products, the creation of Javanese old manuscripts should be considered as a phenomenon in the culture which can be investigated based on culture theories of Koentja-

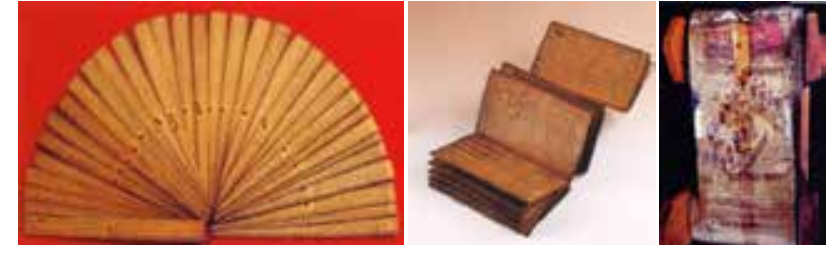

Figure 1. Balinese Lontar Manuscript, Batak Manuscript Pustaha, Makasar Manuscript

(Foto by Damayanti Adisasmito, 2007)

raningrat and on 3 other accompanying forms of cultures, divided as follows: 1) Javanese manuscripts as a record of ideas, thoughts, and content of thinking are illustration of Javanese culture schemes (ideas). 2) Javanese manuscripts are a representations of various kinds of social-life activities. 3)Javanese manuscripts are means of life senses and values which are in the form of book artefacts reflecting high achievement of Javanese intelectuality in writing and visual art (practices)

In creating something human beings are generally inspired by existing factors, and so were old art practicionists in Java. Their creativity is based on "knowledge" and existing art works of the past. In this research, knowledge means "tradition" - which is a bunch of inheritances on what and how art works are created based on the society interpretation of that era. The development of Javanese visual art since pre Hinduism, Hinduism-Buddhism, Islamic, and colonialism eras is basically the development of culture and aesthetic achievement referring to the needs of the society of that era.

\section{Comprehending Manuscripts and Writing Tradition in Java}

Javanese manuscripts are important records and generally have historical values. Most of them which have been changed and adopted, especially those of $1800-1900$ s, are recomposition products and are in the forms of traditional songs called macapat. Most of them were written 150 years ago, during the end of colonialism era till the beginning of Indonesian Independence Revolution era. They are written by those who have strong correlation to Javanese kingdom society. Some of them includ drawings such as illustrations which are visual art products of the Javanese.

Writing is a highly supported activity, and the authors of that era are intelectuals who are strategically capable of recording sociopolitical genres, not only representing about future predictions but also putting them into reality. Penulis (Authors) in Javanese tradition are active practionists in authority and are authorized for full freedom. The word Penulis in Javanese society comes from Javanese language panulis, penyerat - i.e. those who are physically write a manuscript. An author is a composer (panganggit, pangiket) who textually and productively arranges (nganggit) and structures (ngiket) the words or texts. He is also the one who is able to interprete and then describe, 
colour, edit, and structure with nedhak - i.e. a freedom of arranging the words in rewriting (nurun, nedhak) a manuscript to become a new version with a new context

\section{The Development and Role of Manuscripts in Javanese Society}

The illustration of Javanese writing tradition has a strong correlation to old stuffs, so that to understand the culture of Javanese visual art should be relevant to understanding Java of the past time. For example; the oldest translation of Ramayana into Javanese macapat was written in 903 AC (After Christ), and Mahabharata in the era of Prabu Darmawangsa in 991 - 1007 AC (Sri Mulyono, 1975:182184). The manuscript of Kakawin Arjuna Wiwaha, in the 11th Century composed by Mpu Tantular contains Javanese spiritual lessons wrapped in Hinduism puppet stories, and is an analogy of describing the struggles of the kings at that era.

According to John Pemberton in his book, Java (2003), most manuscprits written at these periods are about the effects of Dutch colonialim towards Javanese culture, especially those of Javanese kingdoms (Surakarta and Yogyakarta). Some of the manuscripts of $1800-1920$ reflecting illustrations likely represent cultural phenomena of those eras. They are, therefore, history records and one the artefacts is necessarily to understand and investigate.

In the 12th Century Mahabharata Epos was reinterpreted according to the condition and norms of Javanese literatures. It was then localized and recomposed for shadow puppet shows containing symbols of Javanese spiritual lessons (Serat Dewa Ruci and Serat Arjuna Wiwaha) reflecting syncretism and acculturation of Javanese and Hin$\mathrm{du}$ cultures. This manuscript was rewritten by Mpu Sedah and has become a reference of puppet stories and their varieties until now.

Hindu Classic Javanese Literary Art occurred during the era of Hindu-Buddha. The most popular manuscripts telling about the golden era of Majapahit are Pararathon written by Mpu Tantular and Negarakertagama by Mpu Prapanca. Both describe the condition of the golden reign of Majapahit which is in accordance with Hindu and Buddha in both complexity and harmony paradigm.

Concepts of king Gods and Gods of Buddha-Mahayana in the Hindu Javanese kingdom and Islamic eras give huge influences to the present politics and governance in Java. This is reflected in the manuscripts on the royal family tree which always put gods at the first level of the tree. Palaces are the centres of the spiritual power influencing the life of the society, and of the royal governance and residences.

When Islam reached Java, Islamisation by moslem intelectuals occurred and the quality and spirituality of religious activities increased. This can be seen in the de- velopment of transformative concepts, reflected in the old Javanese manuscripts of the 19th century. Egalitarian system of Islam succeeded in fading the differences between the hierarchies of Majapahit kingdom. Harmonious Islam sufic and mystical way of thinking acculturates with local mystism strongly derived from the tradition of Javanese. Islam education system providing Pesantren (Islamic boarding schools), instead of Padepokan (dormitories) in the Hindu era, plays an important role in proliferating Islam religion. Pesantren, which is still well know until now, is also a place where the culture of readng and writing was introduced and fast developed. This brings about the development of the culture of books and manuscripts written congruent with Islam. Rewriting the Holy Koran and Hadists leads to the development of calligraphy and mushaf. That was the time when Islamic culture and Indonesian intelectuality reached the top, when literacy of Arabic, local languages, and Malay was made possible for the society, and when illuminations and illustrations were made possible after the introduction of daluang paper.

\section{Conditions of Socio-culture on the Colonialism Era}

Discrepancies on the development of art and culture occured at the beginning of the 17 th to the middle of the 18 th centuries as a result of the Dutch's devide et impera politics. This condition brought about civil wars among Javanese kings and rebellions towards the Ducth government which occured longer than 1 century. In addition; this period result in other important events leading to the change of the hierarchy of the Javanese society. For exampe; in 1740 the Chinese ethnic group rebelled. Javanese Successeion War (1746 - 1757), Giyanti Agreement in 1755 stopped the war among Mataram kings, which resulted in the division of Mataram kingdom into small kingdoms, Surakarta and Yogyakarta. Blambangan kings also fought to each other, and the last war was Java War led by Pangeran Diponegoro (1825 - 1830), and many other events (Parakitri, 2007).

At the same time, global politic crisis attacked Europe as a result of the French Revolution. This crisis indirectly influenced European colonies in Asia, leading to the conflict among Europeans in Asia. It also caused the changing in political strategies of West colonialisastion in Asia regions and the changing in the Dutch government in Java. In addition; another crisis happened in 1799, when VOC (Dutch East India Company) was stipulated bankrupt and was eventually dispersed, and then Indonesia was taken over by the Dutch Kingdom. It was at this transition period when Indonesian nationalism emerged (Lombard, 1996). At the same century moderate Islamic culture regained its peak in Indonesia, influencing the way of thinking of the Javanese.

The transition of VOC to the Government of the Dutch Royal in 1799 - 1800 and the global socio-politic condition in Europe during the French Revolution, on the re- 
sponsibility of Daendels, made the French colonialize Java. In 1811 -1815 on the hand of Raffles, the British had a chance to take control of Java, and he made a success in applying liberalism. In 1815, the British gave the control of Java to the Dutch when eventually they succeeded in driving Islamic kingdoms in the coastal areas of Java to the hinterland (Pemberton, 2005).

Moreover; human bondage which changed into Ethic Politics was conducted. This politics was identical to the Dutch force labor system (cultuur stelsel) subjected to the Javanese. On the other hand; the Javanese was directed to adjust their way of thinking to the Dutch way, and some of them were forced to become the Dutch army to fight other European colonizers in Asia - the French and British (Ricklefts,2001).

The condition of royal elites and kings was engineered of that sort to become a culture pledge of Javanese kingdoms (Lombard, 1996). The intervention of foreign imperialists made the local elites and aristocrats not to have an attempt in physically fighting back on them. They made spiritual and intelectual movement instead of changes towards modernisation of thinking, and technology development caused the Javanese to have wider intelectuality. Then there emerged the movement of "modern awareness" which made the Javanese had the strong willingness to be independent society (Florida, 1995). They poured out their expectation in the art and culture products, one of which was writing manuscripts because of the support of the Dutch. Manuscripts written at this period were intended to unite the people to rebuild moral and mental crisis of the Javanese as a result of West materialistic culture and Dutch capitalist system.

The Dutch applied the culture politic strategy, and since then European colony and the intenvention of the Dutch directly came into the Javanese culture. This strategy had changed the way of thinking of the Javanese who had been physically and mentally down (Florida, 1995). Kings were driven to become aristocrats because they no longer had any military and naval power. They stopped getting enggaged in politics and this directly refrained the society from the communication with outside world. However; this condition had spiritually and physically changed and enlightened their thinking, and had indeed significant effects on their culture products.

The Dutch order to study the old Majapahit literary art and rewrite old manuscripts had made the Javanese intelectuals effectively use the chances for spiritual movements in developing their culture. They were also encouraged to write more literary art works and resulted in the rise of Javanese literary art. The translation of foreign literary works, adoption of old literary works, and the production of new literary works by kings and their poets noted this era, commonly called as the Renaisance of Javanese clas-

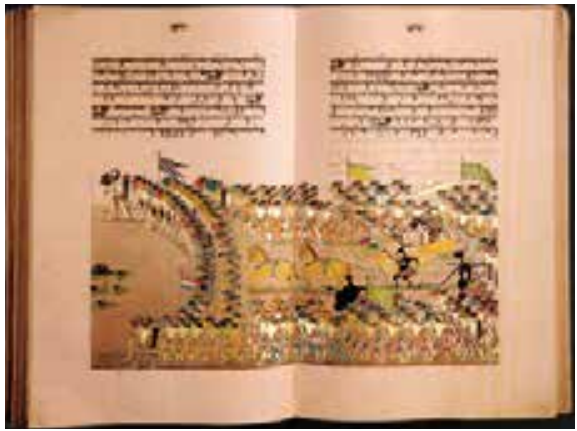

Figure 2. Serat Bharatayudha,1902-1903, History of The Last Biggest War in Indonesia. Content of Manuscript Illustration in as a War Strategic “The Supithurang”. Museum Library Widya

Budaya Collection, Jogyakarta Palace

(Foto By Damayanti Adisasmito, 2007)

sic literary art.

\section{Illustrations on Javanese Manuscripts as the Reflection of Javanese Socio-culture Reality}

Changes on old manuscript writing make poets, in expressing social messages, agree to use modern symbols - i.e. visual languages as modern illustrations adjusted to the changes of their thinking. Those illustrations reflect complexity state and west culture effects. Life values and spiritual-religious thinking change into profane-capitalist thinking. They stlll show cosmology of the Javanese oriented to palaces and kings as the centres of supreme authorities. Kings and aristocrats are still important characters of the manuscripts. Histories of Javanese kings, heroes, and puppet stories - which were not written during the pre-Islam era - are common themes for manuscripts illustrated in shadow puppet shows.

Let's take Serat Bharatayuda as one of the illustratios. The story expresses both explicit and implicit messages about the civil war in Java. There are implicit clues as signals and social symbols for the Javanese to understand. Culture symbols are also applied in the illustrations of manuscripts. In addition; daily life of the society is one of the themes of manuscripts. This shows egalitarian condition and roles of the society significant in the colonialisation era. Importantly, this condition indicates that the cloud is over the authority of absolute kings as the centre of the universe.

Folklores on Panji stories remind us on Javanese cosmologies on roman stories about Javanese hero-to-prince marriages, which are in fact the symbols expressing state cosmologies, cosmic marriages between the lower and upper hierarchies. These social symbols state that palaces, i.e. queenisation (mother earth), united with their peoples (Javanese society) as the power to gain reigns of kingdom - i.e. the independence of Javanese from Dutch colonials. Messages or social signs expressed in the stories are symbols for the unity of peoples and their kings to regain their freedom of life. 


\section{Concepts of Illustration Visuals on Javanese Manu- scripts}

Illustrations on Javanese manuscripts at the era of colonialisation are still traditional art-based concepts, and the techniques are traditional and society based. Techniques and concepts come from generation to generation and are intended, adjusted and refer to the traditions of the creators.

Illustrations at this context are not abstract drawings difficult to interprete, but rather iconographic works because they are representatives of the reality. They are also media of conveying certain mission messages. Objects chosen are processed in such a way that they contain social meaning. Their aesthetic are the products of their visual concepts, not of the perfection of their visual forms. The visual art of the era is, therefore, fine and communicative (Tabrani, 2005).

Tradition of fine art with Hindu Javanese design expresses classic art, and the forms of Islam-designing classic art are found in some regions of the Javanese-Islam kingdoms. The later is in fact developed from that of pre Hindu and Hindu eras. Basic changes on the Islam art products are found in two-dimentional human visualisation. Guardians of Demak kingdom develop wayang kulit (shadow puppets) from wayang Beber of the Majapahit era considered to have Javanese "local content."

Changes of puppet visualisation are adjusted to norms of Islam art - i.e. stillation. These changes occurred during the reign of Raden Patah. At the reign of Sultan Agung, puppets are perfectionized by fining sunggingan decorations, and these are puppets which are still showed until now and as references for modern puppets.

Expressing implicit/symbolic ideas is Javanese life behaviour. Symbolic ways Hindu and Islam are ajusted to local teaching - i.e. original mysticism order of the Javanese meaning that towards manunggaling kawula lan Gus$t i$ (the unity of only God). To the Javanese, understanding something implicit means understanding natural signs and symbols of the ancestors. In other words; understanding moral teaching or mysticism, symbols can keep someone to well, carefully and thoroughly understand the teaching.

The javanese have the adage that wong Jawa enggone semu, papaning rasa, tansah sinamuning samudra, which means "in any activity, the Javanese often use certain social symbols, in any action use feeling, and implicitly do it." Those symbols represent behaviour, abstact and mysterious words and action. This affects the creation of artefacts and fine art products. Old Javanese artists; therefore; present invisible and symbolic symbols.

Illustration Visualisation and Style on Javanese Manuscripts of the $1800-1920 s$

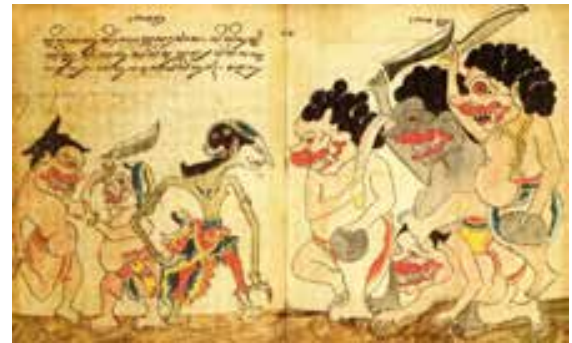

Figure 3. Serat Asmara Supi, 1893, Colletion of Kraton Jogyakarta,

(Foto by Damayanti Adisasmito, 2007)

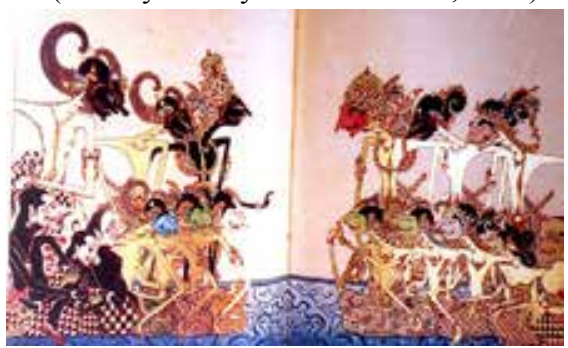

Figure 4. Serat Bratayudha 1902-1903, Colletion of Kraton Yogyakarta, (Foto by Damayanti Adisasmito,2007)

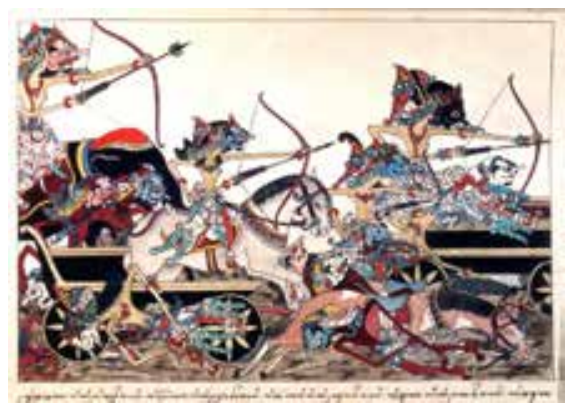

Figure 5. Prang Bratayudha 1857, Ng.Jagaradana, Pathuk, Colletion of Kraton Yogyakarta,

(Foto by Damayanti Adisasmito,2007)

Illustration visualisations on manuscripts of 1800-1920s show typical characters, dominantly expressing puppets. However; they show various characters, forms, themes, and functions. Themes consist of varieties of puppet aspects, Panji (heroes of Javanese society), histories of Javanese kings, and stories on Islamic prophets and guardians. Typical visuals reflect the condition of the time and styles are dominanted by shadow puppets.

Styles on most manuscripts tend to show stillation (simplified form) styles of shadow puppets. This indicates that wayang is the most appreciated visual art, and shows society-rooted Hindu-Buddha-Islam paradigm. Islam paradigm is reflected in the egaliterian concepts and essence of the oneness of God, and pre-Hindu paradigm in the presence of three natures; humans, transcendence and mysticism (microcosmos-metacosmos-macrocosmos) and Javanese art language concepts.

Most of illustration visuals are visible forms. Foreign cultures show sifnificant effects but do not deaden the local characters - i.e. two-dimentional, stillation wayang, orna- 
ments, figures of supernatural creatures (denawa/raksasa) punakawan). Those characters have strong correlation to the colonialisation and to the past time of the Javanese. Pre-Hindu paradigm has continous correlation to visual concepts.

Visuaisation and styles of the illustration on the manuscript of that period can be classified into 3 characters - (1) Stilasi Styles of Wayang Kulit; (2) Combination Stillation Styles of Wayang Beber and Wayang Kulit, (3) Naturalistic-Stillatoni-Realistic-Persfective Styles.

\section{Transformation of Illustration Visualisation and Styles on Javanese Manuscripts of the 1800-1920s}

Culture transfromation on one space and time period correlates to the space and time of the past. The past and future participate in creating a value or meaning of human experiences, and affect the changes of culture artefact production.

The meaning of transformation on human culture products correlates to the continous dimention of human space and time, which is the aspect of character and identity differences of the culture at every era. Culture transformation can change the way of human thinking, and can lead to meaning changes of human towards the values of culture products. Culture transformation of the Javanese contiously occurs. The strategic location of Java Island makes the Javanese keep social contact and interact with various peoples. This has resulted in various adaptation to various cultures, and has made the Javanese develop their way of thinking and have evolutionarily and continously developing culture as a result of the acculturation of various thinking paradigm.

The most dominant paradigm affecting the way of thinking of the Javanese is animism (Pre-Hinduism), Hinduism-Buddhism, Islam and western culture (colonialism). Pre-Hindu culture always is always present from generation to generation, penetrating future space and time.

Most illustrations on the manuscripts show deformative styles of wayang developed as a new version. Normative-to-deformative Styles form the new ones. This transformation enables formal and informal learnig process. There has been formally social interaction among Javanese artists who have western concepts introduced by European artists when visualizing the potraits of Javanese kings in the palaces or indirectly found in developed potraits in Europe. This knowledge then informally spread among the Javanese.

Changes on Javanese illustrations of 1800-1920s obviously seen are stillation styles shifting to naturalistic and realistic. Meditative symbolic characters on gestures and human faces change into expressive metafors. Other changes also present on the narration of implicit message expression. Illustrations expressing ambigous meaning are metaforized culture symbols. The interpretation of this ambigous meaning is necessarily further investigated.

Illustrations remain in such figures as denawa, raksasa, holy animals, ornaments, and shifted objects. Visual forms; however; show changes of two-dimentional characters into naturalistic or limited realistic and nearly naturalistic realistic ones.

Drawing techniques show Javanese perspective way of thinking integrated with western perspective way of thinking. Changes also present on the use of medium, equipment, colouring, and non Javanese characteristic colours.

Ilustration on manuscripts shows the relation between Javanese social life and characters. Reflection of social life is both explicitly and implicitly expressed in the content, visual language, communicative and narrative natures of the illustration, reflecting changing life and order as a result of the interference of a new culture in the Dutch colonialisation era.

The strategy of Dutch culture is to construct an ideology by reintroducing the golden era of Majapahit as a culture reference for the Javanese royal society. Islamic manuscript writing popular at that time was shifted to wayang stories of the Majapahit era.heroic stories and wayang varieties are still symbolically adopted to show obedience to the Dutch. Again the Javanese artists/poets/painters show their local intelectuality through narrative and symbolic visual languages. Islam ideology is implied in wayang stories, people struggles in heroic stories, and king struggles in chronicle manuscripts. Political conflicts between puppet authoroties and the real one are implied in Mahabharat and Bharatayudha. Social signs and symbols present in the illustration, implied and hidden in the communicative language among certain Javanese societies.

Political upheaval and chaos and less effective authorities of Javanese kings because of devide et impera politics of the Dutch are found in the adopted manuscripts of Serat Mahabharata and Bharatayudha, symbolically expressing the fight for authorities and throne among members of royal family.

Self introspection and vertical relation between humans and God The Creator is expressed in the manuscripts of Dewa Ruci, Bima Ruci, Arjuna Wiwaha, etc. Egaliterian similarity between the people and aristocrats is implied in heroic stories reinterpreted from those of Majapahit era, such as Serat Damar Wulan, Panji Jayakusuma, Panji Selarasa, Panji Asmarasupi, etc.

Continous cultural an sociopolitic events have significant effects on various creation of artefacts, and on concept changes of art activities, such as literary art works and 
manuscripts of the 1800-1920s. Illustrations on old Javanese manuscripts are traditional culture products, in which their meaning and interpretation has continously been developed.

Reliefs on temples of Hinduism era, Wayang Beber and Wayang Kulit at the Islam era function as media of ritual activities, philosopy teachings and religion dispersion. In the colonialism era, illustrate manuscripts are used as ritual guidelines, communication media, and means of propaganda for dispersing concepts and politics.

The development of new media, techniques and concepts of visuals makes the forms and styles of illustration on Javanese manuscripts adopt and change in parallel to the functions and characters of the media.western modern knowledge has affected the concepts of art activities. Roles of manuscripts also widen and are used as means of propaganda for concepts and politics, and as means of educating the people.

Illustrations on Javanese manuscripts are tradition fine art, art products before modern era, which are Javanese artbased conception with typical characters. Techniques are traditional ones, which have been used for generations and which are intended, adjusted, and referred to tradition and local life values. Even though palaces no longer applies absolute authorities, illustrations on the manuscripts indicate that way of thinking of the Javanese is still oriented to the royal life and palaces as the centres of authorities. Royal family are still important characters for themes. Forklores and daily life of the society are usually present.

Cultural factors andpolitical changes have shifted the values and roles of the manuscripts. Mpu (practicionists), artists, poets, painters, and writers change their way of thiking and bear new "social awareness," which is found in the process of manuscripr writing and is used to meet the needs at that time.

Furthermore; cultural effects of Islam intelectuals which have developed for 2 centuries have made the Javanese in general have the ability to read and write. This has been a trigger of the birth of poets and itelectuals from ordinary peoples, who are good enough to understand socio-culture problems of that time. Old Javanese manuscripts of the 1800-1920s are important because they provide illustrations interpreting cultural phenomena at that time and written by intelectuals who understand social signs and symbols of the Javanese. They are representative and indiginous visual forms and texts.

\section{CONCLUSION}

The changes of the illustrations on Javanese manuscripts of the 1800-1920s are adjusted to space and time and way of thinking of the society at the colonialism era. Such illustration visuals are reflected in the achievement of fine art aesthetics and way of thniking of the Javanese.

Styles reflect 4 paradigms whch have become framework of thinking for generations - they are Pre-Hinduism (animism), Hiduism-Buddhism (Maturity), Islamic paradigm of Wayang Beber and Wayang Kulit (the oneness of God), and new paradigms - naturalistic, three-dimentional and western perspective visualisation.

\section{The illustrations have the characteristics as follows:}

1) Pre Hinduism way of thinking - isuaisation of animism in the forms of natural and spiritual animals (Ethiology), denawa/raksasa (giants), animal myths, two-dimentional visuals, transcendent, mystical and symbolic expressions. 2) Hindu polytheism, god-goddes characterizations, three-dimentional impression, royal environment and social hierarchy. 3) Monotheism characteristics of Islam, simplified and two-dimentional forms, and realistic expressions of daily and non hierarchy/egaliterian. 4) Western visual concepts through human characterization, naturalistic-relistic-expressive visualisation, and liberal expressions, not bound to norms, and the emergence of individual expressions. 5) The correralations of all characteristics are narrative, symbolic and natural, two-dimentional stillation wayang. The creation of illustration is still dedicated to the kings.

Visual characteristics of stillation wayang have affected illustrtion visualisation and styles of Javanese manuscripts. Transformations of visualisation and styles are the development and styles derived from stillation of Wayang Kulit and Wayang Beber.

\section{Illustration styles on Javanese manuscripts are:}

1) Stillation stillation wayang Kulit humanized or tend to be expressive, though different wombat visualisation, norms remain to be used. 2) Combination of stillation wayang Kulit and Wayang Beber with certain changes. 3) Non wayang styles, visualized close to naturalistic visuals. 4) Deformative and naive. 5) Naturalistic-perspective-limited visuals (the combination of limited perspective of Javanese traditions and perspective techniques as the western way)

Expression of messages in the concept still indicates the continuation of the past, which is in accordance with the Javanese behaviour - symbolic, explicit and implicit. Another visuaisation is meditative in presenting important characters.

\section{External factors leading to transformation:}

1) Globalization and changes of socio-culture-politics in Europe because of the people enforcement, limitation of absolute authorities of kings and imperium system to democracy indirectly influences the colonialisation of the Dutch in Indonesia. These changes have brought about modern awareness and the rise of nation spirits and javaish Javanese through the extraction of tradition fine art 
(genious local). 2) In addition; directions by the Dutch to return to romanticism of Majapahit classical culture and to condition Javanese royal elites and kings as royal culture pledges by the Dutch. This has resulted in art visual concepts of Hinduism classic era as references for art activities. 3) Adjustment to Islamic norms with human egltarian concept has reduced a cult concept of king gods and has shifted to parallel hierarchy of the king and his people. 4) Western methods are introduced when Dutch artists draw a portrait of the king and his royal family. This has significant effects to the royal artists who then spread them to ordinary artists. This can be seen in paintings showing Western perspective styles (three dimentional). 5) The use of media and equipment changes the composition, techniques of paintings, and colouring styles.

Other factors influencing the transformation are internal factors in Javanese culture. There had been limitations of art activities and products by the Dutch, who banned certain art activities considered to threaten the stability of the Dutch government. Such condition, indeed, caused Javanese intelectuals and artists to be socially aware of the social functions of art. They remained to perform art activities as their cultural strategies. They took chances directly incontrast to the Dutch policies - i.e. the order of rewriting old mnuscripts refering to those of Majapahit era. This was an attempt of the Dutch in keeping the royal away Islamic community. Varieties of wayang and heroic stories at the era of Majapahit are raised as an obedience to the Dutch. Those stories are actually a camouflage, and the essence remains the same - i.e. philosopy teaching of the ancestor life with Islamic paradigm, providing cultural symbols symbolically reperesented both explicit and implicit messages. This movement involve the royal and intlectuals/ leaders to influence and educate the people, so that they can take part in regaining their rights of life as an independent nation.

\section{REFERENCES}

Adisasmito, S, 1935, Kitab Dewa Ruci, Pen. Jaw. Keb. Dep. PP \& K Yogyakarta

Ali, Z,1994, Islamic Art in South East Asia, 830AD-1570 $A D$, Percetakan Dewan Bahasa dan Pustaka, Selangor Darul Ehsan.

Amin, D, 2000, Sinkretisme dalam Masyarakat Jawa, Dalam Masyarakat Jawa, Dalam Islam dan Kebudayaan Jawa, Darori Amin(Ed), Jogyakarta, Gama Media

Chamber-Loir,H dan Fathurahman, O, 1999, Khazanah Naskah;Panduan Koleksi Naskah-naskah Indonesia, Sedunia-World Guide to Indonesian Manucript Collection, Seri Naskah dan Dokumen Nusantara, Ecole Francaise d'Extreme-Orient \& Yayasan Obor Indonesia, Cetakan I, Jakarta.
Ciptoprawiro, A, 2000, Filsafat Jawa, Balai Pustaka Damayanti,Nuning, Transformasi Wujud Visual dan Penggayaan Gambar Ilustrasi Jawa Periode 1800-1920, Disertasi, Program Doktor-FSRD ITB, 2007

Florida,N.K., 1995, Writing The Past, Inscribing The Future ( History as Prophesy in Colonial Java), Duke University Press, Durham \& London, 1995

Geertz,C , 1973, The Religion of Java, New York, The Free Press. N.Y.

Graff, H.J. de dan Th.G.Th.Pegeaud, (1985), Kajian Sejarah Politik Abad 15 dan 16 dalam Kerajaan-Kerajaan Islam Pertama di Jawa, Seri terjemahan Javanologi, hasil kerjasama Proyek Penelitian dan Pengkajian Kebudayaan Nusantara dan perwakilan Koninklijk.

Hildawaty, S, 1998, Introduction “ Indonesian:The Art of Archipilago ", Dalam Indonesian Heritage. Vol.7 Visual Art, Singapore, Archipilago Press.

Holt, C, 2000, Melacak Jejak Perkembangan Seni di Indonesia, Penerbit Arti-line, Bandung

Hoop, A.N.J. Th. A.Th. van der : Indonesische Siermotieven,Koninkelijk Bat,Gen. van Kunsten en Wetenschap, 1949

Jong, DR.S.De, 1984, Salah satu Sikap Hidup Orang Jawa, Penerbit Yayasan Kanisius, Jogyakarta

Kempres, A.J.B,1959, Ancient Indonesia Art, C.P.J. Van der Peet Amsterdam, MCMLIX

Koentjaraningrat, (1997), Manusia dan Kebudayaan Indonesia, Djembatan, Jakarta

Kumar, A dan Mc. Glynn, John H., 1996, Illuminations, The Writing Traditions of Indonesia, New York, Published by Weatherhill, Inc. with Lontar Foundation.

Kusuma, S D, Kartakusuma,R, Rosyadi, Heryana A dan Soeratin A, 1997, Aksara, Indonesia Indah, Perum Percetakan Negara Republik Indonesia, Jakarta

Lombard, D, 1996, Nusa Jawa : Silang Budaya, Jilid I,II,III, Gramedia, Jakarta.

Mc. Glynn, J H, 1996, Language and Literatur, dalam Writing Tradition, Oral Tradition in Indonesian Heritage Vol.10, Singapore, Archipilago Press.

Moebirman, 1960, Wayang Purwa, The Shadow Play of Indonesia, The Hague, Amsterdam,

Mulder, N, 2005, Mysticysm in Java, Ideology in Indone- 
sia, Pen. Kanisius, Yogyakarta

Mulyono, S, 1977, Wayang, Asal-Usul dan Filsafat masa Depannya, Gunung Agung, Jakarta.

Ossenbruggen,FDE, 1975, Asal-Usul Konsep Jawa Tentang Mancapat Dalam Hubungan dengan Sistem-Sistem Klasifikasi Primitif, (terj. Koentjaraningrat dkk), Bharata, Jakarta.

Pegeaud,T H., 1962, Java The $14^{\text {th }}$ Century, a Study in Cultural History, Jilid IV, The Hafue, NY.

Pemberton, J, 1994, On The Subject of Jawa, Cornell University, Ithaca, Terjemahan oleh Hadikusumo, Hartono, 2004, Penerbit: Mata Bangsa,Jogyakarta,

Purwadi, 2001, Babad Tanah Jawa, Pen. Pustaka Ali Yogyakarta

Ricklefs,M. C.2005, Sejarah Indonesia Modern 12002004, Serambi, PT.Ikrar Mandiriabadi, Jakarta.

,2006, The Centhini Story, Published by Marshall Cavendish Editions, Singapore.

choemaker, C P W, 1924, Aesthetiek en Oorsprong der Hindoe-Knust of Java, CV Kolf, Bandung.

Simbolon, P T, 2006, Menjadi Indonesia, 2006, Grassindo, PT Kompas Media Nusantara, jakarta

Subagya, R, 1991, Agama Asli Indonesia, Sinar Harapan dan Yayasan Ciptaloka Caraka, Jakarta.

Suseno, F M, 2001, Etika Jawa, Sebuah Analisa falsafi tenteng Kebijaksanaan Orang Jawa, Penerbit PT. Gramedia Pustaka Utama, Jakarta ( 36-135 )

Tabrani, P, 2005., Bahasa Rupa, Penerbit "Kelir", Bandung, Hl.95-110,111-160.

,1999, Sastra Wayang Beber, Lokakarya Penulisan Buku Pintar sastra Jawa, Pusat Pembinaan dan Pengembangan Bahasa, DEPDIKBUD.

ung, Penerbit ITB.

,1998, Message From Ancient Walls, Band-

,1990, Meninjau bahasa Rupa Wayang Beber Jaka Kembang Kuning dari Telaah Cara Wimba dan Tata Ungkapan Bahasa Rupa Media Rupa Rungu Dwimatra Statis Modern Dalam Hubungannya Dengan bahasa Rupa Gambar Prasejarah, Primitif, Gambar Anak dan Relief Cerita Lalita Vistara Borobudur, Disertasi, FSRD, ITB Bandung.
Tjandrasasmita, Uka, tt, Sepintas Mengenai Peninggalan Kepurbakalaan Islam di Pesisir Utara Jawa, Proy. Pelita Pembinaan Kepurbakalaan dan Peninggalan Nasional, Departemen $\mathrm{P} \& \mathrm{~K}, \mathrm{tt}$

Uitgave dan Co, Nederlandsch Indie Oud \& Nieuw 19191920,: Tijdschrift Nederl.Indie oud\& Nieuw Vierde jaargang Amsterdam.

Van Der Hoop, A.N.J.,1949, Indonesia Ornamental Design, Royal Batavia Society of art and Science, Holland.

Yudosaputro, W, 1998, The Early Roots of Indonesian Art, Indonesian Heritage Visual Art, Volume Editor by Hilda Soemantri, Archipelago Press.

,1998, Islamic Influences in Indonesian Art, Indonesian Heritage, Visual Art, Vol.7, Archipilago Press. ,Pen. Buku Antar Bangsa. 